一技術報告一

\title{
火災現場用油資料採取フィルムの検討
}

\author{
橋本 敬 \\ 兵庫県警察本部科学捜査研究所 \\ 干650-8510 神戸市中央区下山手通 5-4-1
}

\section{Performance Assessment of Oil Collecting Film Used at an Arson Scene}

\author{
Takashi Hashimoto \\ Forensic Science Laboratory, Hyogo Prefectural Police H.Q. \\ 5-4-1 Shimoyamate-dori, Chuo-ku, Kobe 650-8510 Japan
}

(Received 22 March 2007; accepted 3 August 2007)

\begin{abstract}
After examining some materials for collecting oil from evidential material at the scene of a fire, we reported that oil clear film ( face oil remover) was the most suitable.

Since oil clear film catches the oil but repels water, we can obtain the oil alone even from evidence that contains water.

Oil can be extracted from the film using a small amount of solvent and analyzed by GC.

This time I made some experiments on contemplating the film performance of oil adsorption.

Each film adsorbed with gasoline, kerosene and diesel oil was extracted at proper time intervals and analyzed with gas chromatograph.

In this way I measured the decrease of adsorbed oil.

The film is capable of detecting kerosene up to 1hour after adsorption and diesel oil up to 1 day after adsorption.

Gasoline is volatile and needs to be contained in the gas barrier plastic bag within 3 minutes after adsorption.

Oil clear film contains something similar to lubricant oil made from petroleum.

Thus, in case of collecting oils containing motor oil like a mixed gasoline, we should use oil clear films after degreasing by solvent.
\end{abstract}

Key words: Oleophic film, Collecting oil, Gasoline, Kerosene, Diesel oil, Gas barrier plastic bag

\section{緒 言 \\ 火災現場の燃焼残椬物に油が含まれるかどうかを} 検査する場合，その資料が大型であったり大量の水
を吸いこんでいたりした場合，破壊の困難な床材な ぞである場合，実験室に持ち込んでの溶媒抽出は困 難である. 
このような（燃焼残椬物に含まれる）油類を現場 で直接採取することを目的として各種の吸着剤を収 集し，その吸着能力について比較検討した.

その結果，オイルクリアフィルム（顔面皮脂吸収 シート）は，ポリプロピレン樹脂製の多孔質のフィ ルムであり，水分をまったく吸着せず油の久を吸着 することから，大量の水を含む資料に押しつけるこ とで油のみを選択的に吸着し，さらに色調が変化す ることで油が吸着されたことを示すなどの特性か ら, 油類の直接採取に最適であった1).

このオイルクリアフィルムは，青い色調の薄いフ ィルムで，顔の皮脂を除去するため「油とりフィル ム」などの名称で市販されている.

フィルムに吸着された油は，時間の経過とともに 低沸点成分から順に揮発し，その成分組成が变化す る. そこで, ガソリン, 灯油, 軽油についてフィル ムに添加し時間をおいて回収したものをガスクロマ トグラフで分析することで，それぞれの油類につい て適切な採取条件を検討した。

オイルクリアフィルムは，石油系の重質油を製品 中に若干含有しており，これは潤滑油類相当のもの である2).そこで，草刈り機など小型の 2 サイクル エンジンによく用いられるガソリンと潤滑油を混ぜ た混合油の採取についても検討を行った。

\section{1. 実験材料}

\section{材料および方法}

\section{（1） オイルクリアフィルム}

油の採取器材としては，顔面の皮脂吸着剂として 用いられている，住友スリーエム株式会社のオイル クリアフィルムを用いた．本品は「油とりフィルム」 などの名称で市販されており，薬局等で購入するこ とができる。

\section{（2）脱油オイルクリアフィルム}

オイルクリアフィルムは製造段階で高沸点の石油 系油類（潤滑油相当の成分）を含んでいるので，こ れを溶媒（ペンタン）に浸けて超音波洗浄し，この 油分を除去（脱油処理）した脱油フィルムを作成し た。

\section{（3）揮発性資料採取袋}

油をオイルクリアフィルムに添加後密封する容器
として，本県で燃焼残椬の採取に用いているナイロ ンーポリエチレンラミネート構造（Fig. 1) の揮発 性資料の採取袋3)を使用した。

\section{2. 実験方法}

（1）油の添加, 回収およびガスクロマトグラフ分 析

オイルクリアフィルムを実際に使用する場合は， 油や燃焼残渣物に押しつけるか，燃焼残さ物を水没 させ，浮いてきた油を水面に浮かせたフィルムに吸 着する (Fig. 2).

今回の実験では，一定量を負荷するためにマイク ロピペットで滴下した。

オイルクリアフィルムを $3 \mathrm{~cm} \times 3 \mathrm{~cm}$ の大きさに カットし，試料の鉱物油を $10 \mu \mathrm{l}$ 添加する．室温で 空気中に一定時間暴露後に約 $10 \mathrm{ml}$ のペンタンで抽 出し, 窒素気流を当て $1 \mathrm{ml}$ に濃縮した抽出液の 2 $\mu \mathrm{l}$ をガスクロマトグラフに注入する.

ガスクロマトグラフの条件は以下の通りである.

Agilent Technologies 社製6890N 型ガスクロマ トグラフ分析装置

カラム DB-5（長さ $30 \mathrm{~m}$, 内径 $0.25 \mathrm{~mm}$, 膜厚 $0.25 \mu \mathrm{m})$

カラム温度設定 $\left(50^{\circ} \mathrm{C} \sim 300^{\circ} \mathrm{C} /\right.$ 毎分 $10^{\circ} \mathrm{C}$ 昇温 $)$

注入口および検出器温度 $280^{\circ} \mathrm{C}$

スプリット注入：スプリット比 $1 ： 50$

また，混合油に対しては潤滑油分析用として以下

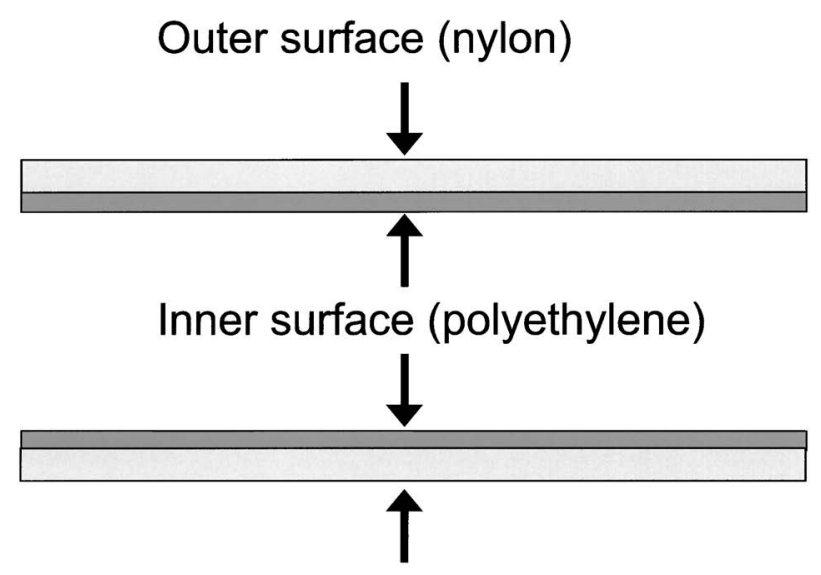

\section{Outer surface (nylon)}

Fig. 1 The layer structure of the gas barrier plastic bag. 


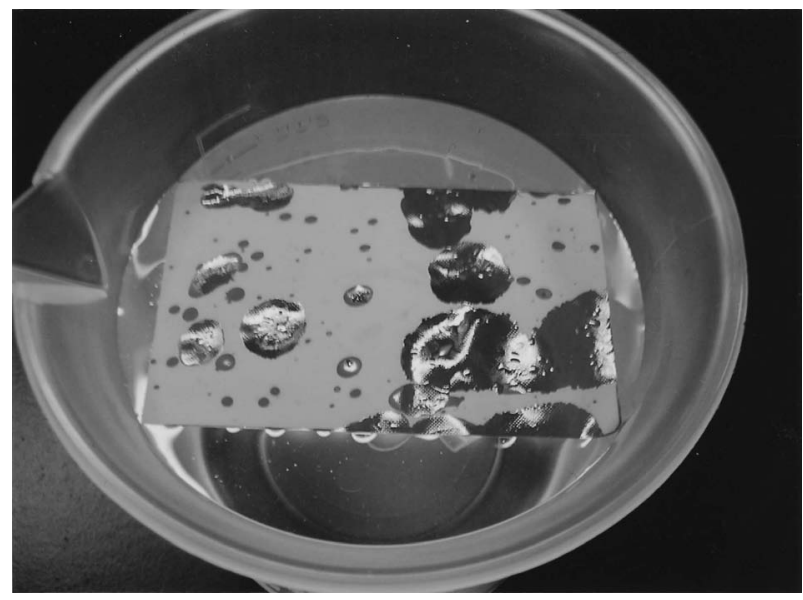

Fig. 2 The film which adsorbed floating oil on the water surface.

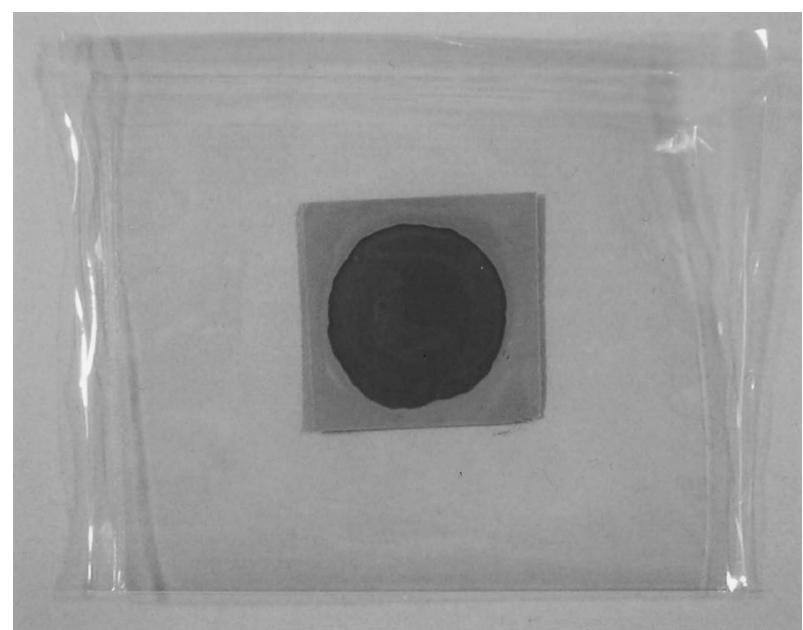

Fig. 3 The film which adsorbed oil is contained in the gas barrier plastic bag.
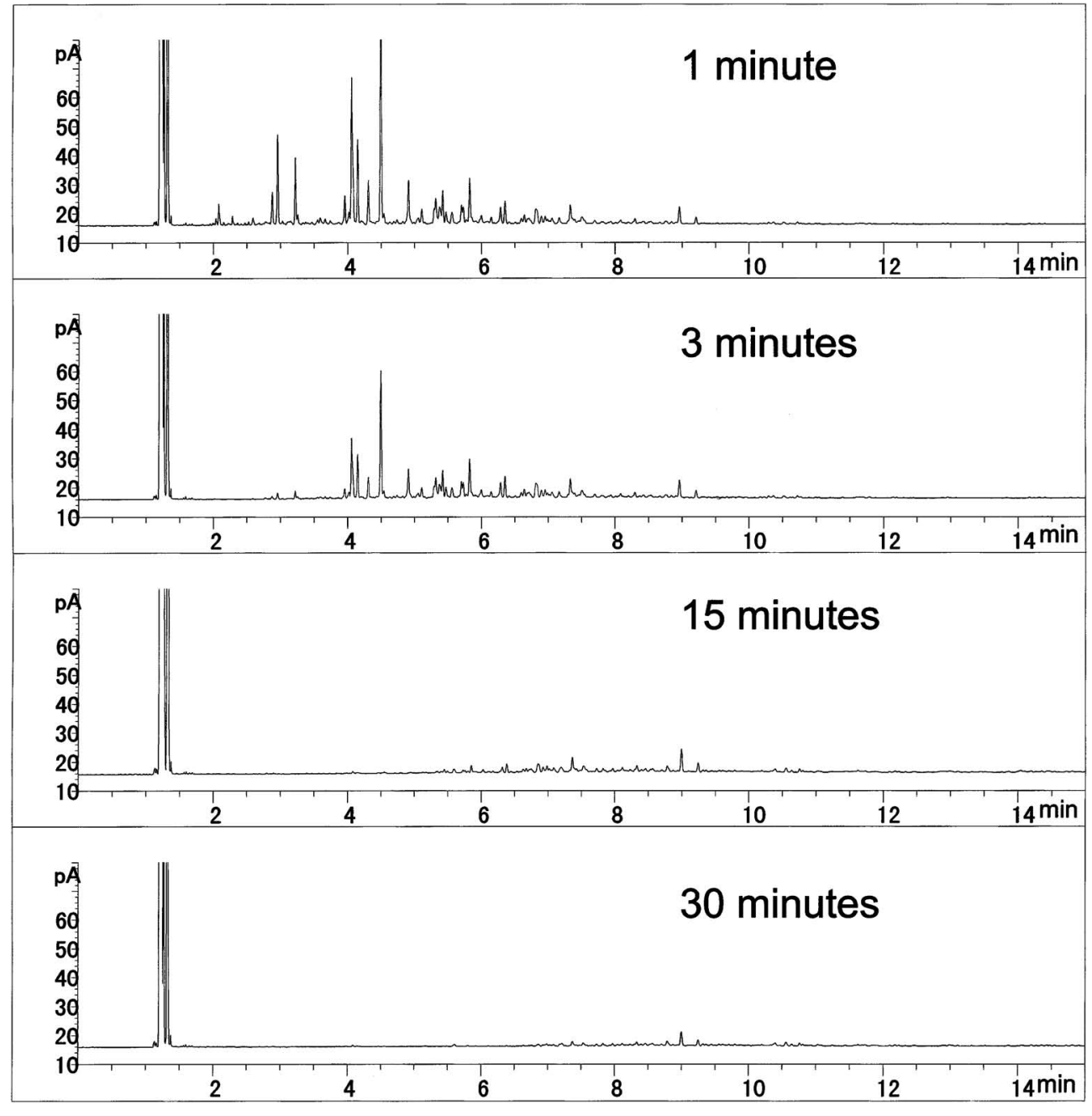

Fig. 4 Gas chromatogram of gasoline extracted from film at each period of time after adsorbed. 
の条件で行った。

島津製作所製 GC2010型ガスクロマトグラフ分 析装置

カラム Ultra Alloy PLUS-1 HT（長さ15 m, 内 径 $0.25 \mathrm{~mm}$, 膜厚 $0.25 \mu \mathrm{m}$ )

カラム温度設定 $\left(50^{\circ} \mathrm{C} \sim 350^{\circ} \mathrm{C} /\right.$ 毎分 $10^{\circ} \mathrm{C}$ 昇温,

$350^{\circ} \mathrm{C}$ で20分保持)

注入口および検出器温度 $300^{\circ} \mathrm{C}$

スプリット注入 : スプリット比 $1 ： 50$

\section{（2）揮発性資料採取袋の使用}

揮発性の高いガソリンについては, 油添加後室温 の空気中に放置したものと揮発性資料採取袋に封入 したもの（Fig. 3）の両方について実験を行い，保 持能力を比較した.

\section{（3）混合ガソリンの捕集実験}

混合ガソリンについては, 通常のオイルクリアフ ィルムと脱油処理をしたオイルクリアフィルムの両 方について添加後回収し，オイルクリアフィルムに 含まれる潤滑油相当の油類の影響について検討し た.

混合ガソリンはガソリンー潤滑油 $(20: 1)$ ぐらい のものが一般的であるが，被熱してガソリンに対す る潤滑油の比率が大きくなったものに近づけるため に，ガソリンー潤滑油（2:1）のものを作成して用 いた。

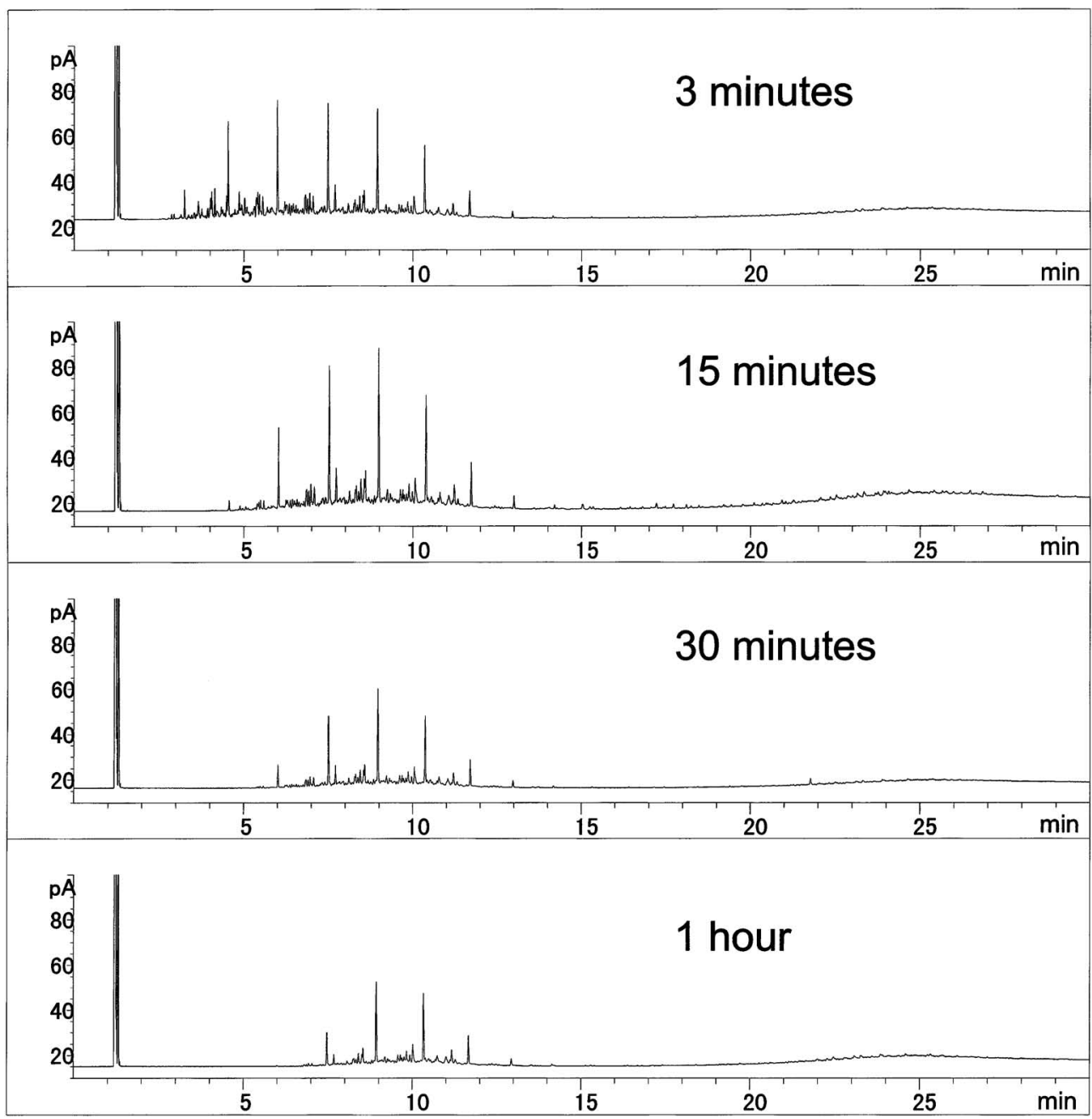

Fig. 5 Gas chromatogram of kerosene extracted from film at each period of time after adsorbed. 


\section{実験結果}

\section{1. 油添加後空気中に暴露した場合}

油を添加した後空気中に暴露した状態で放置し， 溶媒抽出で回収された成分をガスクロマトグラフで 分析した結果について，ガソリンについては Fig. 4 に，灯油についてはFig. 5 にまた，軽油について は Fig. 6 に示した.

ガソリンは，添加後 3 分までの間に，ガスクロマ トグラフの保持時間 0 分から 3 分までの低沸点成分 が大幅に減少している，ただしこの時点ではガソリ ンであることの識別は可能である.

灯油は，ガスクロマトグラフの保持時間 0 分から 5 分ぐらいまでの低沸点成分が消失するのは添加後 15分以降であり, 添加後30分までは成分組成比の大
きな変化はない，灯油は 1 時間以上経過しても，低 沸点側の大きな 3 つの成分ピークが消失している が，識別は十分可能である.

軽油は，ガスクロマトグラフの保持時間 5 分から 10分までの低沸点成分が消失するのは添加後 15 分よ り後であり, 添加 3 時間後でも低沸点側の 2 番目の ピークまでが消失しただけで成分組成比の大きな変 化はない。軽油は 3 時間以上 1 日ぐらいまでに保持 時間10分までの成分ピークが消失しているが，識別 は充分可能である.

\section{2. 油添加後揮発性資料採取袋に密封した場合}

ガソリンを添加後, 揮発性資料採取袋に密封し一 定時間後に抽出してその効果を比較した。その結果 をFig. 7 に示すが，密封し 1 日経過したものは，

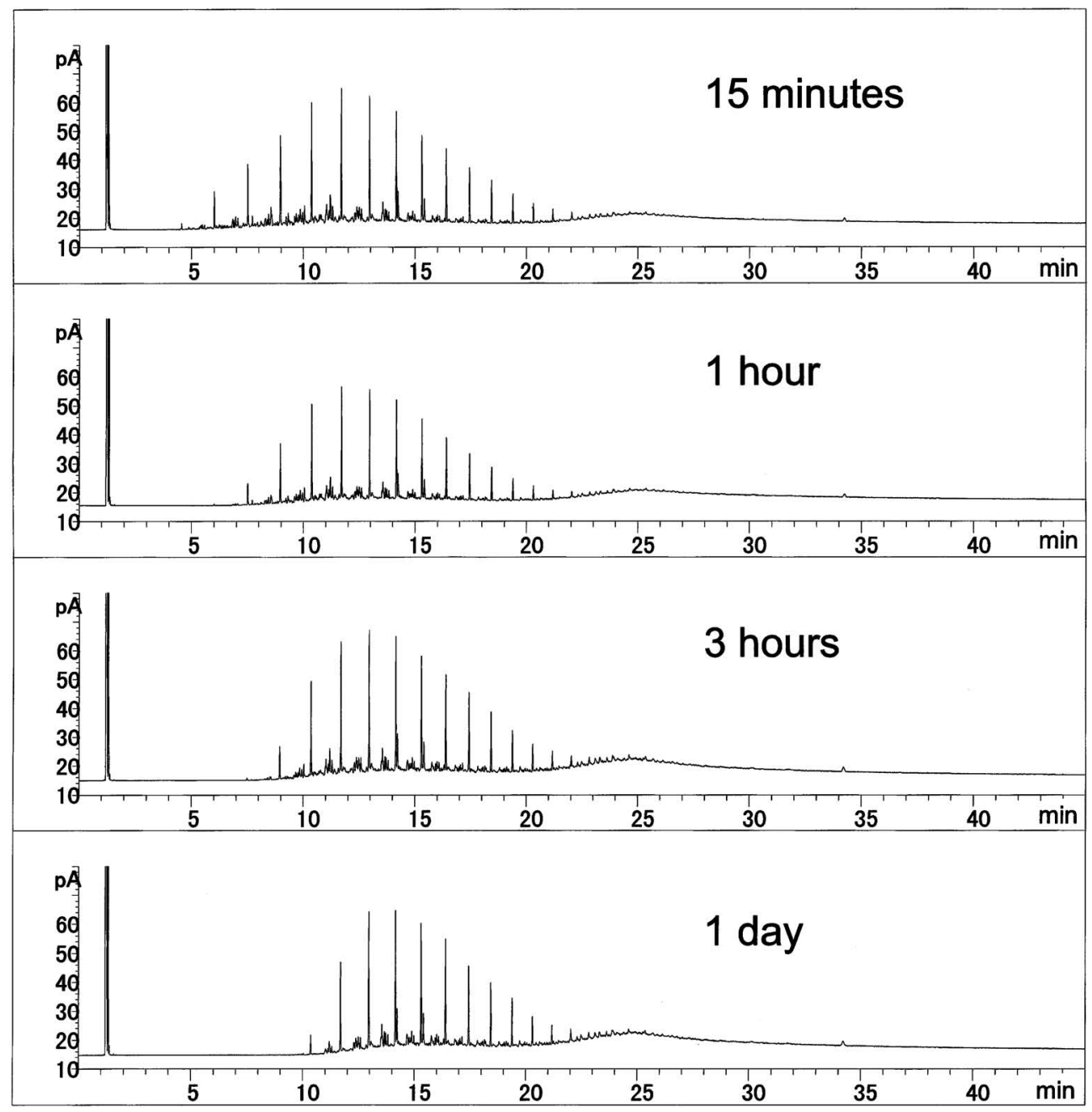

Fig. 6 Gas chromatogram of diesel oil extracted from film at each period of time after adsorbed. 


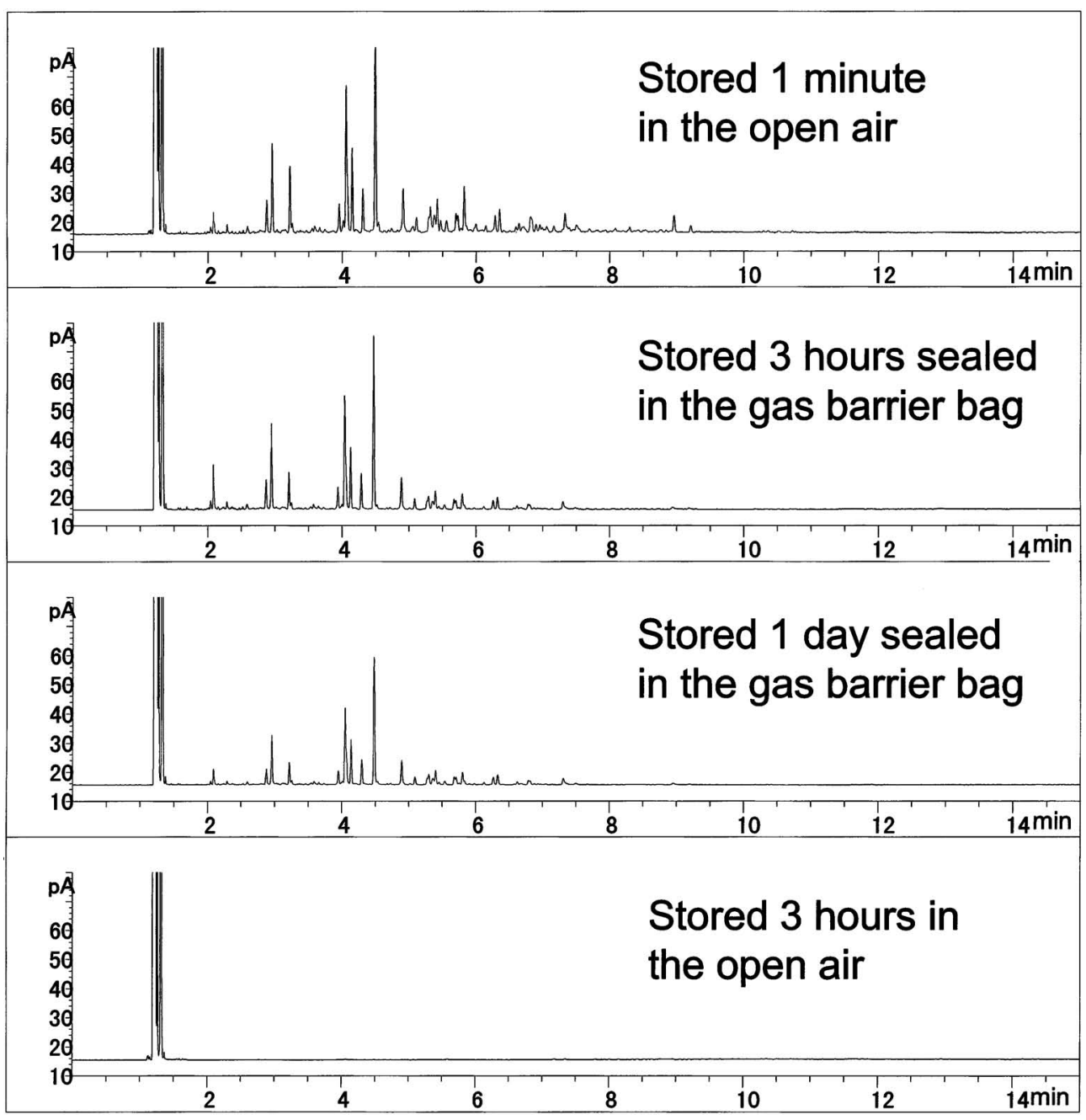

Fig. 7 Gas chromatogram of gasoline extracted from film at each period of time after adsorbed and different storage conditions, sealed in the gas barrier plastic bag and stored in the open air.

空中に暴露して 1 分経過しただけのものと比べて遜 色はなかった。これに対して，空中に暴露したもの は，30分経過すれば識別は困難になる．

以上のことから，揮発性の油類特にガソリンに関 しては，オイルクリアフィルム（以下，フィルムと 記述）で採取した後，揮発性成分を透過しない材質 の密封容器に保存することが必要である.

灯油，軽油については，油捕集後しばらく（灯油 は約 1 時間，軽油は約 3 時間）は保持されている が，実務上は直ちに揮発性資料採取袋に封入するべ きである。

3. 混合ガソリンについて

混合ガソリンについては，未処理のフィルムに添
加し回収したものと脱油処理をしたフィルムに添加 し回収したものの分析結果を Fig. 8 に示した. 添加から回収までの時間は 3 分である.

フィルムに含まれる油と混合ガソリンの 2 サイク ルエンジンオイルの出現する保持時間が一部重なっ ていることが分かる.

このことから混合油のような潤滑油を含む油類の 採取を行うときはフィルムを脱油処理して行うこと が必要であることが分かった。

ただし，添加量が実験にもちいた量（ $3 \mathrm{~cm} \times 3$ $\mathrm{cm}$ に10マイクロリットル）に較べて比較的多い場 合には，フィルムにもともと含まれる油の量がそれ ほど多くないことから, 資料が潤滑油を含むのかど 


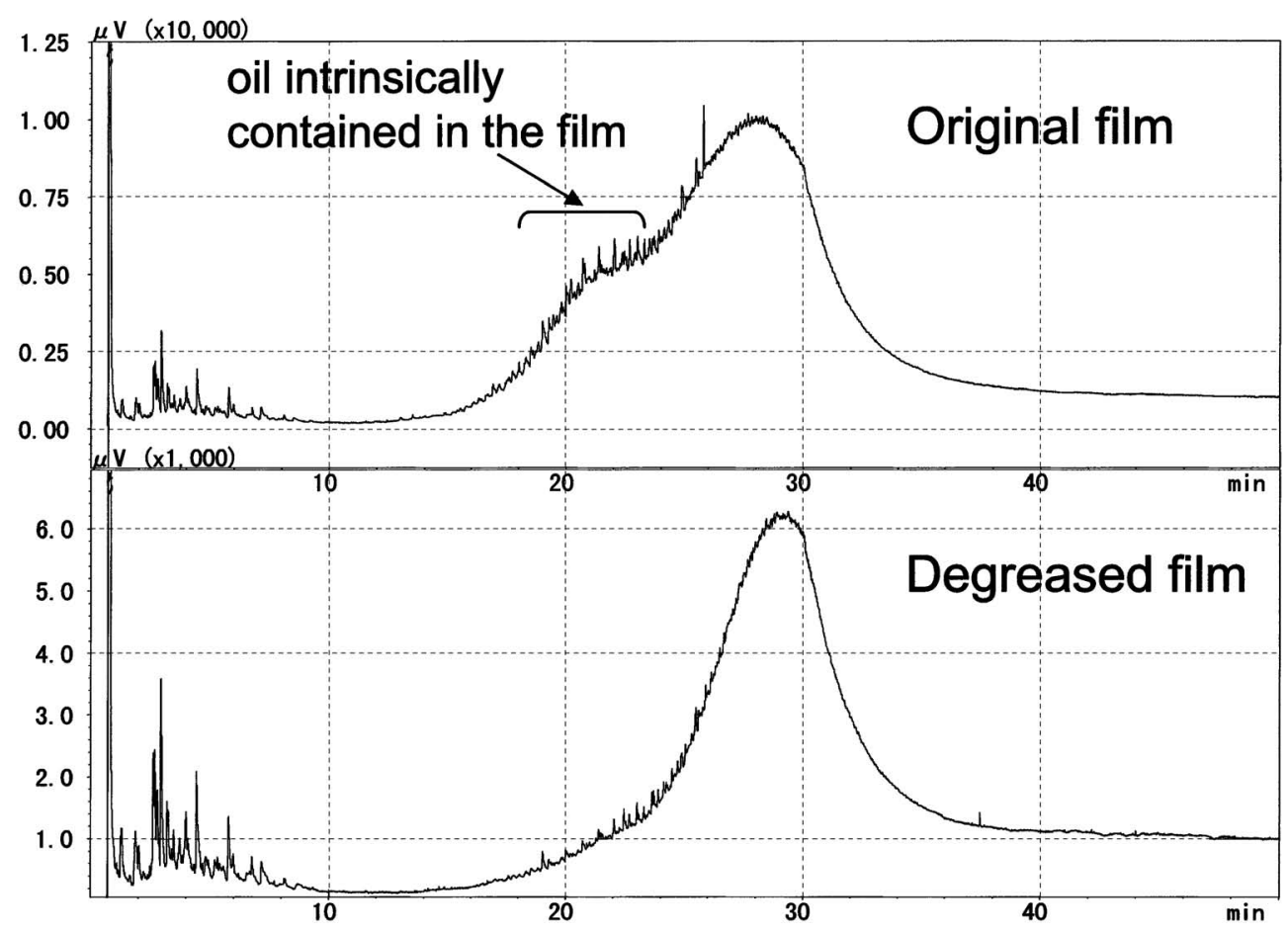

Fig. 8 Gas chromatogram of gasoline extracted from original film and degreased film 3 minutes after adsorbed on the film.

うかという定性検査が可能な場合もあると考えられ る.

しかし，定量的な扱いをしようとするのであれ ば，フィルムを脱油して使用するべきである.

\section{結 語}

ガソリン, 灯油, 軽油について, フィルムへの添 加回収実験を行い，回収した油分をガスクロマトグ ラフ分析によって識別できるために, 空気中暴露の 限界時間について検討した。

ガソリンについては，3 分まで識別可能であっ た。

灯油については，1 時間経過後でも識別可能であ った。

軽油については，3 時間から 1 日経過しても識別 可能であった。

しかし，揮発性資料採取袋に密封した場合はこの 限りではなく，ガソリンでさえ 1 日後まで識別が可 能であった．したがって，すべての資料は採取後に 揮発性資料採取袋に密封して保管することが望まし い.
混合ガソリンについては，潤滑油成分を識別する ためにはフィルムを脱油して用いる必要がある.

\section{謝 辞}

オイルクリアフィルムについて, サンプルとデー タを提供して下さった住友スリーエム株式会社の近 藤一則さんに感謝します。

\section{文献}

1）橋本 敬, 中西俊雄, 高津正久, 宮脇 明, 福 島正雄：軽質油分析に抢ける省溶剂化の検討（第 2 報)一火災現場における油資料の採取方法一。 日本鑑識科学技術学会第 5 回学術集会講演要旨集 平成11年11月, p. 50 (1999).

2）橋本 敬：軽質油分析に抢ける省溶剂化の検討 (第 3 報)一脱油処理したオイルクリアフィルムの 採取特性一. 日本鑑識科学技術学会誌, 第 8 巻別 冊平成15年10月, pp. 43 (2003).

3）橋本 敬：揮発性油類の高分子膜透過性につい て. 鑑識科学研究発表会 (化学部会)講演要旨集, 昭和62年10月, pp28 (1987). 